Editorial

\title{
Publisher's Note: Continued Publication of Pathophysiology, the Official Journal of the International Society of Pathophysiology, by MDPI
}

\author{
Franck Vazquez \\ MDPI, St. Alban-Anlage 66, CH-4052 Basel, Switzerland; vazquez@mdpi.com \\ Received: 18 September 2020; Accepted: 18 September 2020; Published: 22 September 2020
}

check for updates

Pathophysiology (ISSN 0928-4680) was launched in 1994 and has been published during the past 26 years by Elsevier [1,2] as the official journal of the International Society of Pathophysiology (ISP). The ISP was founded in 1991 with a mission to create a platform for global networking in the area of pathophysiology and to foster the versatile development of this branch of physiology [3]. Initially, Pathophysiology was intended to be discontinued in December 2019 [4], but thanks to the kind and generous support of Elsevier, we are very happy to be able to continue the publication of Pathophysiology under the same ISSN and ensure that the legacy of the ISP continues.

We are extremely honored to work closely with Professor J. Steven Alexander [5], who has been the Editor-in-Chief of Pathophysiology for more than five years, with Professor Olga Pechanova, the President of the ISP [6], and with the members of the editorial board to continue to publish significant and impactful articles in this research field.

MDPI's portfolio has greatly expanded in the last few years, and today sums up to 250 journals, in all fields and disciplines [7], including more than 50 journals relevant to the biomedical domain. We are delighted to add Pathophysiology to our biomedical journal portfolio and continue to serve this scientific community well.

We will publish one quarterly issue in 2020 and regularly publish four quarterly issues as of 2021.

Enjoy publishing in Pathophysiology!

Conflicts of Interest: The author is a member of the Management Team of MDPI.

\section{References}

1. Science Direct Page for Pathophysiology. Available online: https://www.sciencedirect.com/journal/ pathophysiology (accessed on 18 September 2020).

2. Journal Statistics Page for Pathophysiology on Scilit.Net. Available online: https://www.scilit.net/journal/ 390631 (accessed on 18 September 2020).

3. About International Society of Pathophysiology. Available online: https://ispweb.cc/about (accessed on 18 September 2020).

4. Elsevier Pathophysiology Journal Homepage. Available online: https://web.archive.org/web/20200823160657/ https://www.journals.elsevier.com/pathophysiology (accessed on 23 August 2020).

5. Alexander Lab. Available online: https://web.archive.org/web/20200918084536/https://www.lsuhs.edu/ departments/school-of-graduate-studies/molecular-and-cellular-physiology/research/alexander-lab (accessed on 18 September 2020). 
6. Homepage of International Society of Pathophysiology. Available online: https://web.archive.org/web/ 20190509141040/https://ispweb.cc/ (accessed on 9 May 2019).

7. MDPI Open Access Journals A-Z list. Available online: https://www.mdpi.com/about/journals (accessed on 18 September 2020).

(c) (1)

(C) 2020 by the author. Licensee MDPI, Basel, Switzerland. This article is an open access article distributed under the terms and conditions of the Creative Commons Attribution (CC BY) license (http://creativecommons.org/licenses/by/4.0/). 